\title{
Financial Statements Analysis
}

Author: Tănase Alin-Eliodor, EVERET România Distribution, alin.tanase@everet.ro

This article focuses on analyzing of a consolidated financial statements of a hypothetically SME. The interpretation of the financial position and performances is based on the more than 40 financial key ratios computed by using financial data from consolidated income statement, consolidated financial position and cash flow. However additional data from notes to financial statements are provided.

Keywords: $\quad$ Financial gearing, Sales per person, EBITDA per person, Sales margin, DSO, DPO, Quick ratio, Cash ratio, DOH, Cash conversion cycle, ROE, ROI, Earnings per share, Dividend payout ratio, Financial leverage index.

JEL Classification: G32 - Financing Policy, Financial Risk and Risk Management, Capital and Ownership Structure, H32 - Firm M41 - Accounting

\section{Introduction}

Calotă (2013, pag. 13) considers accounting as "the main source of knowledge by the management of the real state of economic organization, the one who, through analyzes performed and documents (reports) prepared provide a real and legal decision support". The analyzing of financial statements of SME is an important issue for actual shareholders or new investors and also for the management of SME. This is the reason I write this article which is focused on analyze of 47 financial key ratios split in five categories. This is the second article focused on financial key ratios. The first one is based on 
computed methodology starting from a trail balance of a SME. This present article is referring both on computing the key ratios - starting from financial statements- and analyzing their evolution during four year.

\section{Description of the analyses company}

This point of article is split in 3 parts:

1. Short description and financial statements;

2. Computing the financial ratios;

3. Interpretation of key ratios and conclusions.

\section{Short description and financial statements}

The "ABC" company is included in the category of small and medium sized enterprises because the values from individual financial statements and also the values from consolidated financial statements are falling in thresholds mentioned in Article 2 of the Annex of Recommendation 2003/361/EC:

\begin{tabular}{|l|c|l|l|l|}
\hline $\begin{array}{l}\text { Enterprise } \\
\text { category }\end{array}$ & $\begin{array}{l}\text { Headcount: Annual } \\
\text { Work Unit }\end{array}$ & Annual turnover & OR & $\begin{array}{l}\text { Annual balance } \\
\text { sheet total }\end{array}$ \\
\hline Medium-sized & $50-249$ & $\leq 50.000 .000$ Euro & & $\begin{array}{l}\leq 43.000 .000 \\
\text { Euro }\end{array}$ \\
\hline Small & $10-49$ & $\leq 10.000 .000$ Euro & & $\begin{array}{l}\leq 10.000 .000 \\
\text { Euro }\end{array}$ \\
\hline Micro & $\leq 9$ & $\leq 2.000 .000$ Euro & & $\leq 2.000 .000$ Euro \\
\hline
\end{tabular}

The company has two subsidiaries and it prepares consolidated financial statements. Additional information is also provided. The computing of key ratios is based on the values included in consolidated financial statements:

\section{Consolidated Income Statement}

'ooo

Description

Revenue
2010

20.681
2011

21.889
2012

22.890
2013

22.919 
Cost of sales

\section{Gross profit}

Other operating income

Administrative expenses

Distribution expenses

Other expenses

\section{Profit from operations}

Finance expense

Finance income

Share of post-tax profits of associates

Profit before tax

Tax expense

Profit from continuing operations

Profit attributable to:

Non-controlling interests

Shareholders in Entity ABC

\begin{tabular}{rrrr}
-9.981 & -10.947 & -11.651 & -11.579 \\
\hline 10.700 & 10.942 & 11.239 & 11.340
\end{tabular}

78

86

79

6

$\begin{array}{llll}-1.391 & -1.344 & -1.441 & -1.550\end{array}$

$-5.909$

$-6.365$

$-6.513$

$-6.446$

\begin{tabular}{rrrr}
-86 & -92 & 0 & -160 \\
\hline 3.393 & 3.226 & 3.365 & 3.190
\end{tabular}

$-1.116$

$-912$

$-920$

$-776$

374

217

310

248

\begin{tabular}{rrrr}
51 & 62 & 37 & 40 \\
\hline 2.702 & 2.593 & 2.792 & 2.702
\end{tabular}

\begin{tabular}{rrrr}
-649 & -633 & -641 & -652 \\
\hline 2.052 & 1.960 & 2.151 & 2.049
\end{tabular}

\section{Additional data related to Consolidated Income Statement}

\section{Depreciation \\ and \\ amortization}

Property, plant

and equipment

Intangible assets

Interest expense

Dividend per share

(proposed)

Market price per

share

Staff costs
2010

1.266

107

746

30

658

3.289
210

1.843
187

1.773
220

165

1.931

1.884 


\section{Non-current assets}

Property, plant and equipment

$\begin{array}{llll}11.185 & 10.968 & 11.017 & 11.530 \\ 30.226 & 30.663 & 31.413 & 31.646\end{array}$

Intangible assets

30.226

1.680

1.739

2.149

812

associates

647

616

760

721

Deferred tax assets

448

413

403

405

\section{Total Non-current assets} 44.186

44.400

$45 \cdot 742$

45.115

\section{Current assets}

Inventories

$$
1.443
$$

1.498

1.564

1.640

Trade and other receivables

2.723

$3 \cdot 545$

3.417

3.406

Tax receivables

59

44

21

70

Prepayments

323

299

294

539

Cash and cash equivalents

942

1.083

1.984

1.279

Total Current assets

$5 \cdot 490$

6.469

$7 \cdot 278$

6.934

TOTAL ASSETS

49.676

50.869

53.020

52.048

\section{Liabilities}

\section{Current liabilities}

\begin{tabular}{lcccc} 
Trade and other payables & 7.652 & 8.138 & 7.930 & 8.198 \\
Loans and borrowings & 1.363 & 646 & 1.154 & 3.280 \\
Corporation tax liability & 184 & 181 & 185 & 183 \\
Provisions & 176 & 176 & 213 & 183 \\
\hline Total Current liabilities & 9.376 & 9.141 & $\mathbf{9 . 4 8 2}$ & $\mathbf{1 1 . 8 4 3}$ \\
Non-current liabilities & 0 & 0 & 0 & 0 \\
Loans and borrowings & 11.222 & 11.834 & 12.641 & 10.567 \\
Employee benefits & 838 & 1.124 & 1.363 & 1.065 \\
Provisions and other liabilities & 836 & 779 & 837 & 906 \\
Deferred tax liability & 3.425 & 3.324 & 3.334 & 3.043 \\
\hline Total Non-current liabilities & $\mathbf{1 6 . 3 2 2}$ & $\mathbf{1 7 . 0 6 1}$ & $\mathbf{1 8 . 1 7 5}$ & $\mathbf{1 5 . 5 8 2}$ \\
\hline Total Liabilities & $\mathbf{2 5 . 6 9 8}$ & $\mathbf{2 6 . 2 0 2}$ & $\mathbf{2 7 . 6 5 7}$ & $\mathbf{2 7 . 4 2 6}$ \\
\hline NET ASSETS & $\mathbf{2 3 . 9 7 8}$ & $\mathbf{2 4 . 6 6 7}$ & $\mathbf{2 5 . 3 6 3}$ & $\mathbf{2 4 . 6 2 2}$
\end{tabular}




\section{Issued capital and reserves attributable to owners of the parent}

\begin{tabular}{lcccc} 
Share capital & 1.051 & 1.051 & 1.051 & 1.051 \\
Reserves & -2.430 & -3.010 & -2.230 & -4.737 \\
Retained earnings & 23.505 & 24.642 & 25.376 & 27.039 \\
\hline $\begin{array}{l}\text { Equity, shareholders in Entity } \\
\text { ABC }\end{array}$ & 22.125 & 22.683 & 24.196 & 23.352 \\
Non-controlling interest & 1.853 & 1.985 & 1.167 & 1.270 \\
\hline TOTAL EQUITY & 23.978 & 24.667 & 25.363 & $\mathbf{2 4 . 6 2 2}$
\end{tabular}

\section{Additional data related to Consolidated Financial Position 'ooo CU}

Additional data:

2010

2011

2012

2013

Trade and other receivables, from

which

3.370

4.161

4.177

4.126

Sales of goods and services

1.742

2.450

2.451

2.499

On - trade loans

711

696

660

Loans, fair value of hedging

instruments and other

receivables

917

1.000

1.030

967

Trade and other payables

7.652

8.138

7.930 8.198

Trade payables

3.232

3.795

4.085

4.452

Deposits on returnable packaging

440

445

476

561

Other liabilities

3.980

3.898

3.369

3.185

Average number of employees

240

230

200

175

\section{Depreciation and amortization}

Property, plant and equipment

$\begin{array}{rl}8.992 & 9.383 \\ 731 & 1.096 \\ 1.573 & 1.560\end{array}$

10.401

10.340

Intangible assets

1.096

1.153

1.212

Interest-bearing debt

1.560

1.724

1.731 
Number of shares (average, excl. treasury shares if any)

Note: All the above amounts - except dividend per share, market price, no. of employees and number of shares - are shown in '000 CU.

\section{Computing the financial ratios}

For analyzing the data of this hypothetic company $A B C$ the financial key ratios computed are split into 5 categories as follow (see the table no. 1 to 5 ):
1) Asset Utilization ratios
2) Operating Performance ratios
3) Cash Flow ratios
4) Liquidity and Profitability ratios
5) Return on Investment ratios

Key ratios computed based on the above data are presented in the following tables:

\section{Table no. 1 Asset Utilization ratios}

\begin{tabular}{|c|c|c|c|c|c|}
\hline & Financial key ratio & $\underline{2010}$ & $\underline{2011}$ & $\underline{2012}$ & $\underline{2013}$ \\
\hline 1.1 & Working Capital to Sales Ratio & $1.08 \%$ & $1.92 \%$ & $0.66 \%$ & $-0.93 \%$ \\
\hline 1.2 & Sales to Fixed Assets Ratio & $42 \%$ & $43 \%$ & $43 \%$ & $44 \%$ \\
\hline 1.3 & Sales to Administrative Expenses Ratio & 14,86 & 16,29 & 15,88 & 14,78 \\
\hline 1.4 & Sales to Equity Ratio & $86 \%$ & $89 \%$ & $90 \%$ & $93 \%$ \\
\hline 1.5 & Sales per Person & 86.172 & 95.169 & 114.450 & 130.965 \\
\hline 1.6 & Personnel productivity & 6,29 & 5,86 & 6,48 & 6,15 \\
\hline 1.7 & $\begin{array}{l}\text { EBITDA per Person } \\
\text { Accumulated Depreciation to Fixed Assets }\end{array}$ & 19.858 & 19.688 & 23.693 & 26.063 \\
\hline 1.8 & Ratio & $18,04 \%$ & $19,09 \%$ & $20,17 \%$ & $20,39 \%$ \\
\hline 1.9 & Distribution Expenses to Sales Ratio & $28,57 \%$ & $29,08 \%$ & $28,45 \%$ & $28,12 \%$ \\
\hline 1.10 & Investment Turnover & $51,32 \%$ & $52,46 \%$ & $52,57 \%$ & $57,01 \%$ \\
\hline 1.11 & Interest Expense To Debt Ratio & $5,92 \%$ & $5,34 \%$ & $4,76 \%$ & $4,29 \%$ \\
\hline 12 & Financial Gearing & $52,49 \%$ & $50,59 \%$ & $54,39 \%$ & $56,24 \%$ \\
\hline
\end{tabular}




\section{Table no. 2 Operating Performance ratios}

\begin{tabular}{llrrrr} 
& Financial key ratio & $\underline{\mathbf{2 0 1 0}}$ & $\underline{\mathbf{2 0 1 1}}$ & $\underline{\mathbf{2 0 1 2}}$ & $\underline{\mathbf{2 0 1 3}}$ \\
\cline { 2 - 5 } 2.1 & Sales margin & $23,17 \%$ & $20,91 \%$ & $20,65 \%$ & $\mathbf{2 1 , 3 6 \%}$ \\
2.2 & Gross margin & $51,74 \%$ & $49,99 \%$ & $49,10 \%$ & $49,48 \%$ \\
2.3 & Operating profit percentage & $16,44 \%$ & $14,77 \%$ & $14,35 \%$ & $14,59 \%$ \\
2.4 & Net income percentage (Return on sales) & $9,92 \%$ & $8,96 \%$ & $9,40 \%$ & $8,94 \%$ \\
2.5 & Consolidated profit for the year per person & 8,552 & 8,523 & 10,753 & 11,711 \\
2.6 & Operating margin & $16,41 \%$ & $14,74 \%$ & $14,70 \%$ & $13,92 \%$
\end{tabular}

\section{Table no. 3 Cash Flow ratios}

\begin{tabular}{llrrrr} 
& Financial key ratio & $\underline{2010}$ & $\underline{2011}$ & $\underline{2012}$ & $\underline{\mathbf{2 0 1 3}}$ \\
\cline { 2 - 6 } 3.1 & Cash flow from operating activities per share (CFPS) & 225 & 178 & 209 & 166 \\
3.2 & Free cash flow per share (FCFPS) & 110 & 83 & 125 & 5 \\
3.3 & Share price to cash flow ratio & 2,24 & 1,72 & 2,28 & 2,55
\end{tabular}

Table no. 4 Liquidity and solvability ratios

\begin{tabular}{|c|c|c|c|c|c|}
\hline & Financial key ratio & $\underline{2010}$ & $\underline{2011}$ & $\underline{2012}$ & $\underline{2013}$ \\
\hline 4.1 & Accounts receivable Turnover & 11,88 & 10,44 & 9,34 & 9,26 \\
\hline 4.2 & Days sales outstanding (DSO) (in days) & 31 & 35 & 39 & 39 \\
\hline $4 \cdot 3$ & Inventory to sales ratio & 14 & 15 & 15 & 14 \\
\hline 4.4 & Inventory turnover & 6,92 & 7,31 & 7,45 & 7,06 \\
\hline 4.5 & Inventory to working capital & 6,46 & 3,57 & 10,39 & $-7,67$ \\
\hline $4 \cdot 7$ & Days payables outstanding (DPO) (in days) & 118 & 117 & 123 & 135 \\
\hline 4.6 & Payables turnover & 2,72 & 2,77 & 2,65 & 2,42 \\
\hline 4.8 & Current ratio (Golden financing rule) & 0,59 & 0,71 & 0,77 & 0,59 \\
\hline $\begin{array}{c}4.9 \\
4.1\end{array}$ & Quick ratio & 0,43 & 0,54 & 0,60 & 0,45 \\
\hline $\mathrm{o}$ & Cash ratio & 0,10 & 0,12 & 0,21 & 0,11 \\
\hline 4.11 & Current assets turnover & 3,77 & 3,66 & 3,33 & 3,23 \\
\hline $\begin{array}{c}4.1 \\
2 \\
4.1\end{array}$ & Days of inventory on hand (DOH) (in days) & $\begin{array}{c}53 \\
36.48\end{array}$ & $\begin{array}{c}50 \\
3480\end{array}$ & $\begin{array}{c}49 \\
34,20\end{array}$ & $\begin{array}{c}52 \\
42,18\end{array}$ \\
\hline $\begin{array}{c}4.1 \\
3\end{array}$ & Current liability ratio (Leverage structure) & $\begin{array}{c}36,48 \\
\%\end{array}$ & $\begin{array}{c}34,89 \\
\%\end{array}$ & $\begin{array}{c}34,29 \\
\%\end{array}$ & $\begin{array}{c}43,18 \\
\%\end{array}$ \\
\hline
\end{tabular}




$\begin{array}{clrrrr}4.1 & \text { Noncurrent Assets To Noncurrent Liabilities } & & & & \\ 4 & \text { Ratio } & 2,71 & 2,60 & 2,52 & 2,90 \\ 4 \cdot 1 & & & & 31,04 \\ 5 & \text { Short-Term Debt To Long-Term Debt Ratio } & 12,15 \% & 5,46 \% & 9,13 \% & \% \\ 4.1 & & & & & \\ 6 & \text { Interest cover } & 6,39 & 6,80 & 7,22 & 7,67 \\ 4.1 & \text { Cash conversion cycle (net operating cycle) } & -34 & -32 & -35 & -44 \\ 7 & & & & & \end{array}$

\section{Table no. 5 Return on Investment ratios}

\begin{tabular}{rlrrrr} 
& Financial key ratio & $\mathbf{2 0 1 0}$ & $\mathbf{2 0 1 1}$ & $\mathbf{2 0 1 2}$ & 2013 \\
\cline { 2 - 6 } 5.1 & Book value per share & 1.476 & 1.523 & 1.566 & 1.520 \\
5.2 & Return on total assets & $4,13 \%$ & $3,85 \%$ & $4,06 \%$ & $3,94 \%$ \\
5.3 & Return on equity (ROE) & $8,56 \%$ & $7,95 \%$ & $8,48 \%$ & $8,32 \%$ \\
5.4 & Return on equity (ROE) - excluding NCI & $8,33 \%$ & $7,82 \%$ & $7,98 \%$ & $8,07 \%$ \\
5.5 & Return on investment (ROI) & $4,13 \%$ & $3,85 \%$ & $4,06 \%$ & $3,94 \%$ \\
5.6 & Financial leverage index & 2,07 & 2,06 & 2,09 & 2,11 \\
5.7 & Earnings per share & 113,40 & 109,46 & 119,19 & 116,30 \\
5.8 & Dividend payout ratio & $26,46 \%$ & $29,24 \%$ & $27,69 \%$ & $30,09 \%$ \\
5.9 & Dividend yield ratio & $17,24 \%$ & $22,72 \%$ & $17,87 \%$ & $16,18 \%$
\end{tabular}

\section{Interpretation of key ratios and conclusions}

Comments based on above financial key ratios and focused specially for the last two years. The purpose of computing and analyzing of key ratios is to understand the past evolution of SME and to establish the future measures for achieving the shareholders expectation. "If the performance goals were not achieved, then the causes will be established and the required measures will be configured, based on them a new strategy will be configured, according to the new elements." (Calotă, April 2014, page no. 9).

» For the first time during the analyzed period (2010-2013) the working capital is negative caused by significant increase of trade payables of $10 \%$ in 2013 vs. 2012 (insignificant increase of accounts receivables and a slight increase - less than $5 \%$ - of inventory). The impact of trade payable's increase can be noticed when DPO for 2013 is computed: no. of days increased from 123 days (2012) to 135 days (2013). 
» There are no significant changes in evolution of Sales to Fixed Assets Ratio (1\% small increase 2013 vs. 2012) this means that the $5 \%$ increase of tangible fixed assets 2013 vs. 2012 is not a significant one related to the revenue. Also there are no significant changes in evolution of Accumulated Depreciation to Fixed Assets Ratio during 2010-2013.

» The negative evolution of Sales to Administrative Expenses Ratio is clearly generated by $7 \%$ increase of administrative expense (2013 vs. 2012). Generally, this kind of increase should be carefully checked by using additional data. Based on the additional data it can be notice two issues as follow:

- a significant de decrease of number of employees (200 employees in 2012 vs. 175 employees in 2013) but in the same time

- a significant increase of staff costs (" ooo CU) included in income statements ( 3.533 in 2012 vs. 3.729 in 2013)

Apparently there is a contradiction but - in fact- the increase of staff costs is generated by compensation wages granted for laid off employees. These compensation wages are included in administrative expenses. The significant decrease of employees positively influences the evolution of three key ratios:

- $\quad$ Sales per Person (114.450 in 2012 vs. 130.965 in 2013),

- $\quad$ EBITDA per Person (23.693 in 2012 vs. 26.063 in 2013), and

- Consolidated profit for the year per person (10.753 in 2012 vs. 11.711 in 2013)

The lowest Profit from operations amount from the analyzed period (2010-2013) is recorded in 2013 when is recorded the highest value of EBITDA per Person. At first glance it may seem an unusual situation but number of employees has decreased much faster in 2013 vs. 2012 (12 \%) than Profit from operations ( $5 \%$ decreases in 2013 vs. 2012).

The significant increase of staff costs negatively influences the evolution of Personnel productivity (6.48 in 2012 vs. 6.15 in 2013). Anyway the lowest value of Personnel productivity has been recorded in 2011 (5.86 in 2011). It can be notice that the personnel costs is almost the same in $2011 \mathrm{v}$. 2013 but the value of revenue for 2011 is $4.5 \%$ less than revenue for 2013.

" In the last two years there is a positive evolution - but without significant impact - of Distribution Expenses to Sales Ratio (0.13 \% revenue increase vs. $1 \%$ distribution expense decrease). 
" There is a positive evolution during 2010 - 2013 for Finance expense and Interest Expense To Debt Ratio. SME has borrowed money at lower interest rates. The total balance amount of short and long term interest - bearing debt increased during the last 3 years. This increase has generated the evolution of Financial Gearing. Anyway the SME has preferred to borrow money from banks instead of borrow money from shareholders by increasing the share capital.

» The evolution of Sales margin and Gross margin indicate that SME has maintained its profitability. The same conclusion can be notice from evolution of Operating profit percentage. During 2010-2013 there is a slight decrease for all these three key ratios; the lowest value is recorded in 2012. This decrease can be considered to be normal due to the fact that - in the analyzed period - the revenue increased (5.84 \% in 2011 vs. $2010 ; 4.75 \%$ in 2012 vs. 2011) and it is possible that the SME offered better conditions (e.g. increasing of commercial discounts) to its customers or to record higher distribution expenses.

» The above mentioned administrative expense increase (7\% in 2013 vs. 2012) has a notable negative impact regarding the evolution of Operating margin and a slightly negative influence of Return on sales because the negative influence is diminished by the positive evolution of financial costs ( decrease $15.6 \%$ in 2013 vs. 2012).

"The solvency ratio expresses the degree to which the company copes with total liabilities, the way its assets are able to deal with the liabilities incurred. A solvent entity is able to pay its creditors." (Calotă \& Vintilescu, October 2013, page no. 10).

» The evolution of cash flow key ratios is not good and suggests a lack of liquidity, especially from operating activities. This lack of liquidity can be noticed more clearly when the value of Quick ratio and Cash Ratio are analyzed. These two ratios are less than 1. As a common rule, if these ratios are less than 1 it indicates that SME can have significant difficulties regarding the payments for current liabilities. Even Current ratio - also known as Golden financial rule - is less than 1. It expresses the relationship between current assets and current liabilities. Generally, if this ratio is:

a) 1:1 is considered to be the absolute minimum level of acceptable liquidity;

b) Less than 1 it indicates that SME might have significant difficulties regarding the payments for current liabilities. 
» Likewise, it can be notice that the amount of short term liabilities increased in 2013 vs. 2012. The total of short and long term liabilities remained constant in 2013 vs. 2012 but there is an important increase of proportion of the total liabilities which must be paid in a period less than one year. However this ratio doesn't indicate the ability of SME to pay its current liabilities. In the same time can be notice that there is a significant switch from long term category to short term category. This is clearly indicated by evolution of Short-Term Debt to Long-Term Debt Ratio $5.46 \%$ in 2011, 9.13\% in 2012 and 31\% in 2013). Days sales outstanding is the same in 2012 and 2013 (39 days) but Days payables outstanding increase in 2013 with 11 days vs. 2012 and this may be a sign of lack of liquidity.

» The evolution of Return on Investments Key ratios indicates that the SME has a constant evolution. There are no significant changes. It is important to notice that Dividend payout ratio increased in 2013. The highest value has been recorded in 2013. There is a constant dividend policy.

$\mathrm{ABC}$ is a stabile enterprise. The evolution for the last 4 years is good, especially regarding the increase of revenue. The future fixed costs, especially staff costs, will be low in the next years due to the significant reduction of employees. It is a good sign the fact that this decreasing of employees didn't affect the sales increasing. The evolution of market share price is good (the prices are constantly increasing). This is a good sign for shareholders. However the enterprises have a poor liquidity. This part must be carefully motorized by management. It can be noticed a constant policy for distribution of dividends. This is also a good sign for investors.

\section{Acknowledgement}

This paper has been financially supported within the project entitled "Horizon 2020 - Doctoral and Postdoctoral Studies: Promoting the National Interest through Excellence, Competitiveness and Responsibility in the Field of Romanian Fundamental and Applied Scientific Research", contract number POSDRU/159/1.5/S/140106. This project is co-financed by European Social Fund through Sectoral Operational Programme for Human Resources Development 2007-2013. Investing in people! 


\section{References}

[1]. Barry J. Epstein and Nadira M. Saafir, (2010), GAAP Practical Implementation Guide and Workbook, published by John Wiley \& Sons, Inc., Hoboken, New Jersey;

[2]. Calotă, T.O., (2013), Contabilitate. De la teorie la practică. Metodă și modelare, Editura Universitară, București;

[3]. Calotă, T.O., (April 2014), Impact Of Information Organization on Performance in Tourism, article published in Journal of Knowledge Management, Economics and Information Technology, Vol. IV, Issue 2, http://www.scientificpapers.org/economics/impact-ofinformation-organization-on-performance-intourism/http://www.scientificpapers.org/wpcontent/files/1456_Impact_of_Information_Organization_on_Perfor mance_in_Tourism.pdf

[4]. Calotă, T.O., Vintilescu, D.T., (October 2013), Case Study on Analysis of Financial Statements at a Furniture Manufacturer, article published in Journal of Knowledge Management, Economics and Information Technology, Vol. III, Issue 5, online edition ISSN: 20695934, http://www.scientificpapers.org/economics/case-study-onanalysis-of-financial-statements-at-a-furniture-manufacturer/

[5]. http://www.scientificpapers.org/wpcontent/files/1413_CalotaVintilescu-

Case_study_on_analysis_of_financial_statements_at_a_furniture_m anufacturer.pdf

[6]. Gherghina, R., Duca, I., (2012), „Gestiunea financiară a intreprinderii”, University Publishing House, Bucharest;

[7]. Ulrich Wiehle, Michael Diegelmann, 100 US GAAP Financial Ratios, Cometis AG, Unter den Eichen7, 65195 Wiesbaden, Germany

[8]. OMFP 3055/2009, The Accounting Regulations complying with the Fourth EEC Directive and the Sevenths EEC Directive. 